\title{
Photoelectrochemical solar cell fabrication with tungsten diselenide single crystals
}

\author{
M K AGARWAL, V V RAO and V M PATHAK \\ Department of Physics, Sardar Patel University, Vallabh Vidyanagar 388 120, India \\ MS received 25 November 1988; revised 31 January 1989
}

\begin{abstract}
Recent reports on highly efficient photoelectrochemical solar cells with $n$-type $\mathrm{WSe}_{2}$ have prompted us to grow $n$-type single crystals of $\mathrm{WSe}_{2}$ using a chemical vapour transport method. Different transporting agents have been used. It is seen that $\mathrm{SeCl}_{4}$ transporter leads to very large single crystals of $p$-type $\mathrm{WSe}_{2}$, whereas the same transporting agent with excess amount of Se leads to $n$-type single crystals. PEC solar cells fabricated with $p$-type and $n$-type crystals thus grown have been reported and the results discussed.
\end{abstract}

Keywords. Photoelectrochemical solar cells; tungsten diselenide; single crystals.

\section{Introduction}

Investigations are constantly under progress to develop new potential materials for solar energy conversion and for improving the conversion efficiency. It is essential in liquid junction solar cells that the semiconductor should be stable under conditions of illumination and the environment of the electrolyte. The recent interest in transition metal dichalcogenide layered compounds therefore originates from their potential for solar conversion. Among the dichalcogenides, those containing the group VI semiconductors have particularly desirable properties for both Schottky and liquid junction solar cells (Tributsch 1977, 1978). These materials exhibit band gap energies in the optimum range for solar energy conversion (Mattheis 1973; Hovel 1975; Kautek et al 1980) and have sufficient high absorption so that only a thin layer of the semiconductor is needed for the conversion of solar to electrical energy (Frindt 1963; Beal and Hughes 1979). In addition to these, Lewerenz et al (1980) and Parkinson et al (1980) have found that these semiconductors have a low susceptibility to photo corrosion due to phototransition between hybridized metal $d$-bands which leave the bonding of the illuminated semiconductor largely unaffected.

From photoelectrochemical studies on the transition metal dichalcogenides, the most efficient systems reported so far are based on the $n-\mathrm{WSe}_{2} \mathrm{I}^{-} / \mathrm{I}_{2}$ junctions. The results obtained by different workers have been summarised in table 1 .

The attainment of such a high efficiency with $n-\mathrm{WSe}_{2}$ single crystals led us to concentrate our efforts on the growth of $n$-type $\mathrm{WSe}_{2}$ crystals.

\section{Growth of $\mathrm{WSe}_{2}$ single crystals}

$\mathrm{WSe}_{2}$ crystals can be grown either by using a direct vapour transport method or a chemical vapour transport method. Successful attempts to grow them by the direct vapour transport method have been made by the authors. All the crystals grew in the form of platelets directly above the distributed charge in the ampoule. The 
Table 1. Maximum efficiency reported by different authors with $n$-WSe $\mathrm{W}_{2} \mathrm{PEC}$ solar cell.

\begin{tabular}{|c|c|c|c|}
\hline Type & Electrolyte & Reference & $\begin{array}{c}\text { Efficiency } \\
(\eta \%)\end{array}$ \\
\hline$n$-WSe ${ }_{2}$ & $\begin{array}{l}0.5 \mathrm{M} \mathrm{H}_{2} \mathrm{SO}_{4}+ \\
0.5 \mathrm{M} \mathrm{Na}_{2} \mathrm{SO}_{4}+ \\
1.0 \mathrm{M} \mathrm{NaI}^{+}+ \\
0.025 \mathrm{M} \mathrm{I}_{2}\end{array}$ & Fan et al (1980) & $14 \cdot 0$ \\
\hline$n-\mathrm{WSe}_{2}$ & $\begin{array}{l}1.0 \mathrm{M} \mathrm{NaI}^{0.05 \mathrm{M} \mathrm{I}_{2}}\end{array}$ & Kline et al (1981) & $10 \cdot 2$ \\
\hline$n-\mathrm{WSe}_{2}$ & $\begin{array}{l}2.0 \mathrm{M} \mathrm{KI}^{+} \\
0.005 \mathrm{M} \mathrm{I}_{2}\end{array}$ & Campet et al (1987) & $22 \cdot 0$ \\
\hline$n-\mathrm{WSe}_{2}$ & $\begin{array}{l}1 \mathrm{M} \mathrm{KI}^{+} \\
0.05 \mathrm{M} \mathrm{I}_{2}\end{array}$ & $\begin{array}{l}\text { Prasad and } \\
\text { Srivastava (1988) }\end{array}$ & $17 \cdot 1$ \\
\hline
\end{tabular}

largest size crystal had dimensions of $18.0 \times 6.6 \times 0.6 \mathrm{~mm}^{3}$. However, all these crystals were found to be $p$-type semiconductors. In order to grow $n$-type $\mathrm{WSe}_{2}$ crystals $\mathrm{SeCl}_{4}$ and $\mathrm{Br}_{2}$ were used as the transporting agents.

Stoichiometric amounts of tungsten powder ( $99.999 \%$ pure) and spectroscopic standard $\left(99.999 \%\right.$ pure) selenium powder were sealed under a pressure of $10^{-5}$ torr in $25 \mathrm{~mm}$ inner diameter $\times 22 \mathrm{~cm}$ length quartz ampoules. Prior to the introduction of the elements the quartz ampoules were thoroughly cleaned, etched and vacuum baked.

The ampoule was then placed in a two-zone horizontal furnace, which had a linear temperature gradient, at a temperature of $800^{\circ} \mathrm{C}$ for 3 days for the preparation of the polycrystalline material. The polycrystalline $\mathrm{WSe}_{2}$ material was then introduced in another ampoule of similar dimension and the transporting agent $\mathrm{SeCl}_{4}\left(2-3 \mathrm{mg} / \mathrm{cm}^{3}\right)$ was introduced. The ampoule was evacuated to a pressure of less than $10^{-5}$ torr prior to sealing. After thorough mixing the ampoule was again kept in the furnace with a temperature gradient of $5^{\circ} \mathrm{C} / \mathrm{cm}$ for a period of 5 days. All the crystals obtained were black, opaque and platelike with the $c$-axis normal to the plane of the plates. All of them grew vertical to each other directly above the distributed charge in the ampoule. Figure 1 shows the crystals thus grown.

These crystals are very smooth and have exceptionally flat faces. Study of microstructures reveals a large number of crystallographically-oriented spirals on the grown faces of these crystals which suggests a screw dislocation mechanism of the growth for these crystals. A typical spiral is shown in figure 2. The results obtained so far have been shown in table 2 .

A careful study of table 2 reveals the following:

(a) $\mathrm{SeCl}_{4}$ transporting agent leads to the growth of large single crystals of $p$-type $\mathrm{WSe}_{2}$. These crystals have exceptionally flat faces with smooth surfaces.

(b) $n$-type single crystals can also be grown with $\mathrm{SeCl}_{4}$ transport with excess amounts of selenium $\left(0.22 \mathrm{mg} / \mathrm{cm}^{3}\right)$, but they are relatively much smaller in size and have rough surfaces.

(c) From Hall coefficient measurements, we have ascertained that the crystals grown by $\mathrm{SeCl}_{4}$ with excess amount of selenium are $n$-type semiconductors by nature. 


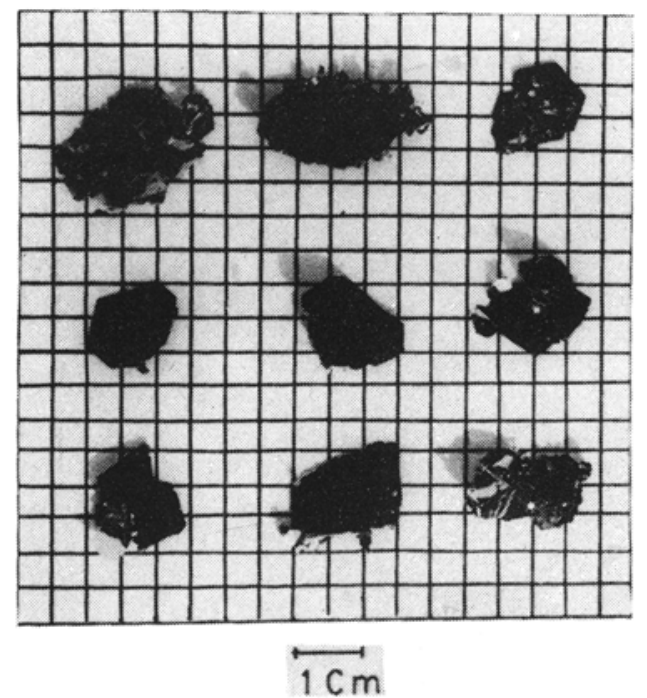

Figure 1. Large crystals of $p$ - $\mathrm{WSe}_{2}$ grown using $\mathrm{SeCl}_{4}$ as a transporting agent.

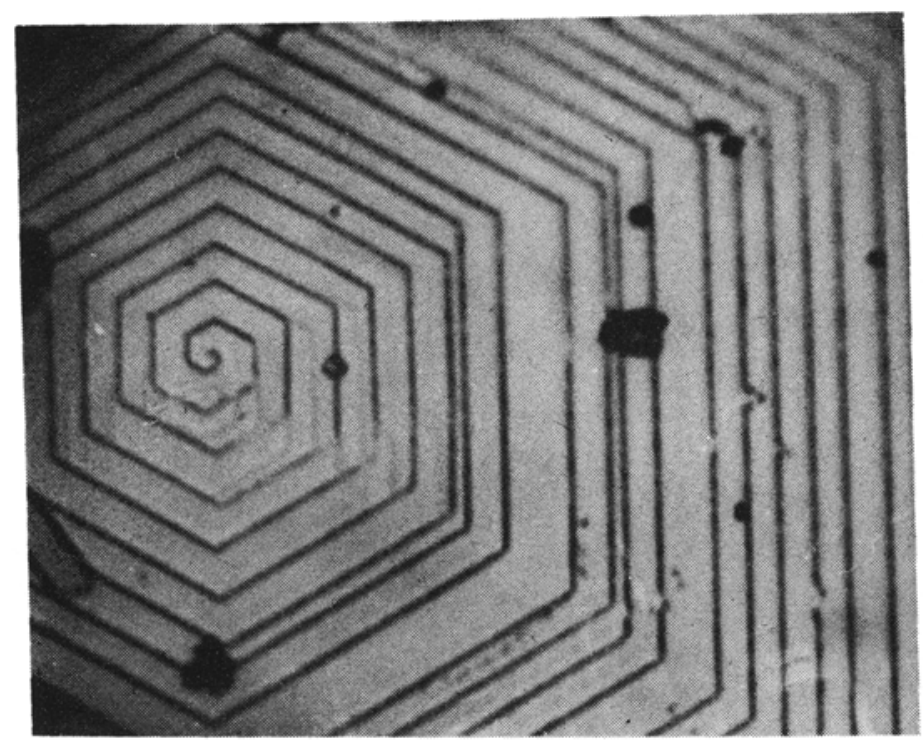

Figure 2. Hexagonal spiral originating from the centre of an $n$-type $\mathrm{WSe}_{2}$.

\section{Cell fabrication with $p-\mathrm{WSe}_{2}$ single crystals}

Photoelectrochemical solar cells (PEC) have been fabricated using the above grown single crystals as photoelectrodes and platinum grid as counter electrode. The cell has been so designed that the electrolyte can be changed without disturbing the electrodes. Different types of electrolytes have been tried and checked by changing the individual concentrations. Finally those electrolytes giving better photovoltage 
Table 2. Growth parameters for $\mathrm{WSe}_{2}$ single crystals grown by using different transporting agents.

\begin{tabular}{lccccc}
\hline & \multicolumn{2}{l}{$\begin{array}{l}\text { Temperature } \\
\text { gradient }\left({ }^{\circ} \mathrm{C}\right)\end{array}$} & & & \\
\cline { 2 - 5 } $\begin{array}{l}\text { Transporting } \\
\text { agent }\end{array}$ & $\begin{array}{c}\text { Hot } \\
\text { zone }\end{array}$ & $\begin{array}{c}\text { Cold } \\
\text { zone }\end{array}$ & $\begin{array}{c}\text { Growth time } \\
\text { (h) }\end{array}$ & $\begin{array}{c}\text { Size of the crystal } \\
(\mathrm{mm} \times \mathrm{mm} \times \mathrm{mm})\end{array}$ & Type \\
\hline $\mathrm{SeCl}_{4}$ & 980 & 950 & 120 & $20 \times 15 \times 0.6$ & $p-\mathrm{WSe}_{2}$ \\
$\mathrm{SeCl}_{4}$ & 990 & 960 & 112 & $2 \times 3 \times 0.5$ & $n-\mathrm{WSe}_{2}$ \\
$\mathrm{SeCl}_{4}+\mathrm{Se}$ & 980 & 950 & 100 & $3 \times 3 \times 0.5$ & $n-\mathrm{WSe}_{2}$ \\
$\mathrm{Br}_{2}$ & 970 & 940 & 108 & $6 \times 5 \times 0.6$ & $p-\mathrm{WSe}_{2}$ \\
\hline
\end{tabular}

Table 3. Efficiency, fill factor, current density and open circuit voltage of $p$-WSe $\mathrm{W}_{2}$ single crystal PEC solar cells using different electrolytes.

\begin{tabular}{|c|c|c|c|c|}
\hline Electrolyte & $\begin{array}{l}\text { Efficiency } \\
\qquad(\eta \%)\end{array}$ & Fill factor & $\begin{array}{l}\text { Current density } \\
J_{\text {s.c. }}\left(\mathrm{mA} / \mathrm{cm}^{2}\right)\end{array}$ & $\begin{array}{c}\text { Open circuit voltage } \\
V_{\text {o.c. }}(\mathrm{mV})\end{array}$ \\
\hline $\begin{array}{l}0.2 \mathrm{M} \mathrm{FeCl}_{2}+ \\
0.1 \mathrm{M} \mathrm{FeCl}_{3}+ \\
1 \mathrm{M} \mathrm{H}_{2} \mathrm{SO}_{4}\end{array}$ & 0.25 & $0 \cdot 307$ & 1.25 & $65 \cdot 0$ \\
\hline $\begin{array}{l}2 \mathrm{M} \mathrm{NaI}+ \\
0.5 \mathrm{M} \mathrm{Na}_{2} \mathrm{SO}_{4}+ \\
0.5 \mathrm{M} \mathrm{H}_{2} \mathrm{SO}_{4}\end{array}$ & 0.87 & 0.381 & 2.08 & $110 \cdot 0$ \\
\hline $\begin{array}{l}0.2 \mathrm{M} \mathrm{K}_{4} \mathrm{Fe}(\mathrm{CN})_{6}+ \\
0.01 \mathrm{M} \mathrm{K}_{3} \mathrm{Fe}(\mathrm{CN})_{6}+ \\
0.05 \mathrm{M} \mathrm{KCl}^{-}\end{array}$ & $1 \cdot 23$ & 0.341 & 2.70 & 134.0 \\
\hline $\begin{array}{l}0.1 \mathrm{M} \mathrm{K}_{4} \mathrm{Fe}(\mathrm{CN})_{6}+ \\
0.1 \mathrm{M} \mathrm{K}_{3} \mathrm{Fe}(\mathrm{CN})_{6}+ \\
1 \mathrm{M} \mathrm{KCl}\end{array}$ & 3.95 & 0.487 & $5 \cdot 41$ & $150 \cdot 0$ \\
\hline
\end{tabular}

and photocurrent have been selected. Using these electrolytes, the open circuit voltage, short circuit current density, fill factor and efficiency have been measured. The results are given in table 3.

By studying table 3, we conclude that

(a) In all the four different electrolytes, the ferri/ferrocyanide electrolyte gives better results with $p$-WSe ${ }_{2}$ electrodes.

(b) Ferri/ferrocyanide electrolyte with concentration $0.1 \mathrm{M} \mathrm{K}_{4} \mathrm{Fe}(\mathrm{CN})_{6}+0.1 \mathrm{M}$ $\mathrm{K}_{3} \mathrm{Fe}(\mathrm{CN})_{6}+1 \mathrm{M} \mathrm{KCl}$ gives an efficiency of $3.95 \%$. The effect of variation of the intensity of incident illumination on open circuit voltage, short circuit current density, fill factor and efficiency has been examined. The results have been shown in table 4 . The $I-V$ characteristic curve has been shown in figure 3.

It can be seen from table 4 that:

(a) The efficiency is maximum at minimum intensity of illumination on the semiconductor electrode and vice versa.

(b) Short circuit current density and open circuit voltage increase continuously with increase in the intensity of illumination. 
Table 4. Efficiency, fill factor, current density and open circuit voltage measured at different intensities of $p$-WSe $2 / 0 \cdot 1 \mathrm{M} \mathrm{K}_{4} \mathrm{Fe}(\mathrm{CN})_{6}, 0 \cdot 1 \mathrm{M} \mathrm{K}_{3} \mathrm{Fe}(\mathrm{CN})_{6}$ and $1 \mathrm{M} \mathrm{KCl} / \mathrm{pt}$ electrode cell.

\begin{tabular}{lcccc}
\hline $\begin{array}{l}\text { Intensity } I \\
\left(\mathrm{~mW} / \mathrm{cm}^{2}\right)\end{array}$ & $\begin{array}{c}\text { Efficiency } \\
(\eta \%)\end{array}$ & $\begin{array}{c}\text { Fill factor } \\
(\text { F.F. })\end{array}$ & $\begin{array}{c}\text { Current density } \\
J_{\text {s.c. }}\left(\mathrm{mA} / \mathrm{cm}^{2}\right)\end{array}$ & $\begin{array}{c}\text { Open circuit voltage } \\
V_{\text {o.c. }}(\mathrm{mV})\end{array}$ \\
\hline 10 & 3.95 & 0.487 & 5.41 & 150.0 \\
20 & 2.53 & 0.454 & 6.87 & 162.0 \\
30 & 1.75 & 0.411 & 7.50 & 170.0 \\
50 & 1.32 & 0.417 & 8.33 & 191.0 \\
100 & 0.8 & 0.408 & 9.79 & 200.0 \\
\hline
\end{tabular}

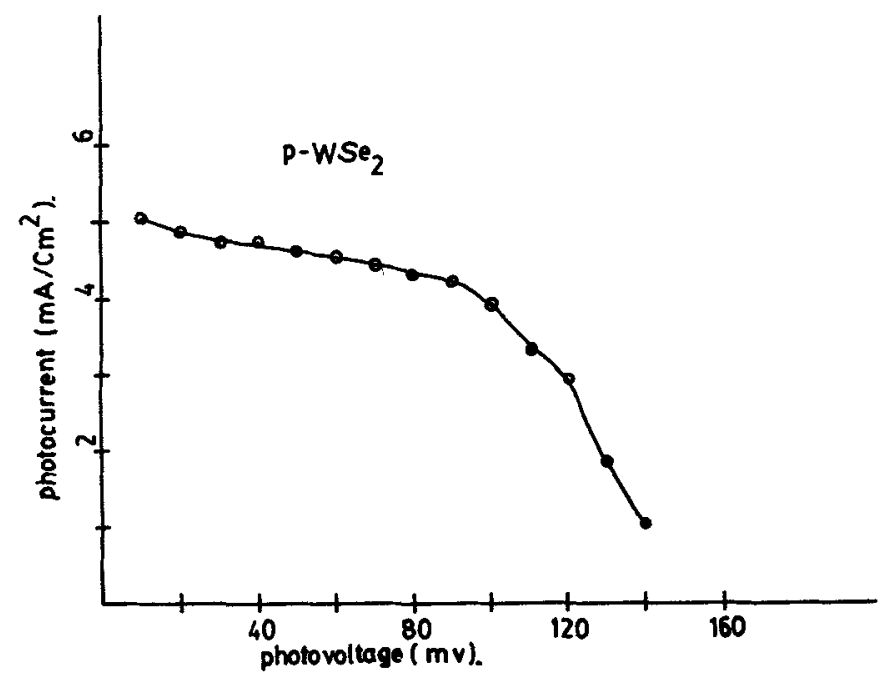

Figure 3. I-V characteristic curve of a $p-\mathrm{WSe}_{2}$ PEC solar cell.

Photoelectrochemical solar cells have also been fabricated with $n$-type $\mathrm{WSe}_{2}$ single crystals using different types of electrolytes. The results are shown in table 5 and the $I-V$ characteristic curve is shown in figure 4.

It is seen that the results are very poor. The lower values of efficiency obtained with these crystals as electrodes is because the crystals have rough surfaces with a large number of steps upon them.

Efforts are therefore being made to grow large crystals of $n$-type WSe ${ }_{2}$ with fairly smooth surfaces. Prasad and Srivastava (1988) suggested that the efficiency of the PEC cells fabricated with as-grown crystals of $\mathrm{WSe}_{2}$ can be greatly improved by photoetching. It was therefore thought that the efficiency of cells fabricated using $n$-type and p-type materials can also be greatly improved by proper surface treatments. Results of some of the preliminary experiments made are given below.

Treatments like electrode heating in air and chemical etching with different etchants on the fabricated cell surface were carried out. The efficiency before treatment with as-grown crystals was $0.7 \%$ and it improved after treatment to $5 \%$. This work is still in progress and shall be communicated in due course. 
Table 5. Efficiency, fill factor, current density and open circuit voltage of $n$-WSe $\mathrm{W}_{2}$ single crystal PEC solar cell using different electrolytes.

\begin{tabular}{|c|c|c|c|c|}
\hline Electrolyte & $\begin{array}{l}\text { Efficiency } \\
(\eta \%)\end{array}$ & Fill factor & $\begin{array}{l}\text { Current density } \\
J_{\text {s.c. }}\left(\mathrm{mA} / \mathrm{cm}^{2}\right)\end{array}$ & $\begin{array}{c}\text { Open circuit voltage } \\
V_{\text {o.c. }}(\mathrm{mV})\end{array}$ \\
\hline $\begin{array}{l}0.2 \mathrm{M} \mathrm{FeCl}_{2}+ \\
0.1 \mathrm{M} \mathrm{FeCl}_{3}+ \\
1 \mathrm{M} \mathrm{H}_{2} \mathrm{SO}_{4}\end{array}$ & 0.017 & $0 \cdot 210$ & $6 \cdot 10$ & $5 \cdot 7$ \\
\hline $\begin{array}{l}0.2 \mathrm{M} \mathrm{K}_{4} \mathrm{Fe}(\mathrm{CN})_{6}+ \\
0.01 \mathrm{M} \mathrm{K}_{3} \mathrm{Fe}(\mathrm{CN})_{6}+ \\
0.5 \mathrm{M} \mathrm{KCl}\end{array}$ & 0.073 & 0.416 & 3.90 & $9 \cdot 0$ \\
\hline $\begin{array}{l}0.1 \mathrm{M} \mathrm{K}_{4} \mathrm{Fe}(\mathrm{CN})_{6}+ \\
0.1 \mathrm{M} \mathrm{K}_{3} \mathrm{Fe}(\mathrm{CN})_{6}+ \\
1 \mathrm{M} \mathrm{KCl}\end{array}$ & 0.23 & 0.286 & 1.95 & $21 \cdot 0$ \\
\hline $\begin{array}{l}2 \mathrm{M} \mathrm{NaI}+ \\
0.5 \mathrm{M} \mathrm{Na}_{2} \mathrm{SO}_{4}+ \\
0.5 \mathrm{M} \mathrm{H}_{2} \mathrm{SO}_{4}\end{array}$ & 0.52 & 0.248 & 1.46 & $35 \cdot 0$ \\
\hline
\end{tabular}

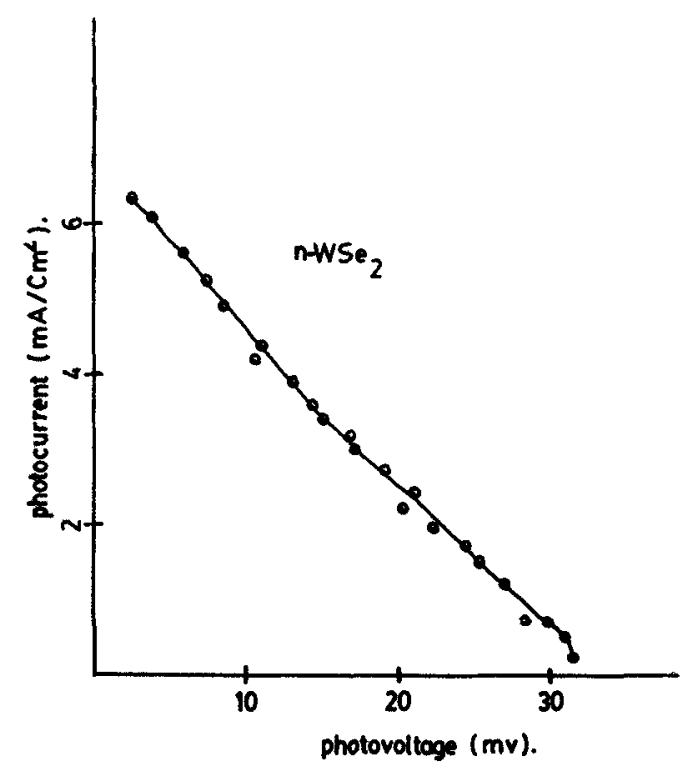

Figure 4. I-V characteristic curve of an $n-\mathrm{WSe}_{2}$ PEC solar cell.

\section{Conclusion}

The behaviour of PEC solar cells is very sensitive to crystal selection and orientation. Successful regenerative operation of a semiconductor liquid junction solar cell requires change in either the electrolyte composition or the semiconductor surface.

Our results show that layered semiconductor $n-W_{S e}$ exhibit a number of steps on their surface. Either improved growth processes, leading to large area smooth samples, or the invention of a method to suppress the disadvantageous effects of the 
steps on layered semiconductors appear highly desirable for the fabrication of an efficient PEC cell.

\section{Acknowledgement}

One of the authors (VVR) is thankful to the Department of Non-Conventional Energy Sources for financial assistance.

\section{References}

Beal A R and Hughes H P 1979 J. Phys. C. 12881

Campet G, Azaiez C, Levy F, Bourezc H and Claverie J 1987 (private communication)

Fan R F, White H S, Wheeler B and Allen B J 1980 J. Electrochem. Soc. 127519

Frindt R F 1963 J. Phys. Chem. Solids 241107

Hovel H J 1975 Semiconductors and semimetals (eds) R K Willardson and A C Beer (New York: Academic Press) vol. 11

Kautek W, Gerischer H and Tributsch H 1980 J. Electrochem. Soc. 1272471

Kline G, Kam K, Canfield D and Parkinson A B 1981 Solar Energy Mater. 4301

Lewerenz H J, Heller A and Disalvo F J 1980 J. Am. Chem. Soc. 1021877

Mattheis L F 1973 Phys. Rev. B 83729

Parkinson B A, Furtak T E, Canfield D, Kain K and Kline G 1980 Faraday Discuss. Chem. Soc. 70233

Prasad G and Srivastava O N 1988 J. Phys. D.: Appl. Phys. 211028

Tributsch H 1977 Ber. Bunsenges. Phys. Chem. 81361

Tributsch H 1978 J. Electrochem. Soc. 1251086 